\title{
PENERAPAN METODE $K$-MEANS CLUSTERING DALAM PEMETAAN DOSEN TEKNIK KELISTRIKAN KAPAL PPNS
}

\author{
Farizi Rachman $^{1}$, Denny Oktavina Radiant ${ }^{2}$, Ika Erawati ${ }^{1}$, Afif Zuhri Arfianto ${ }^{3}$ \\ ${ }^{I}$ Jurusan Teknik Permesinan Kapal, Politeknik Perkapalan Negeri Surabaya \\ ${ }^{2}$ Jurusan Teknik Bangunan Kapal, Politeknik Perkapalan Negeri Surabaya \\ ${ }^{3}$ Jurusan Teknik Kelistrikan Kapal, Politeknik Perkapalan Negeri Surabaya \\ email:farizirachman@ppns.ac.id
}

\begin{abstract}
ABSTRAKS
Politeknik Perkapalan Negeri Surabaya (PPNS) merupakan Perguruan Tinggi pendidikan vokasi yang bergerak di bidang perkapalan dan teknologi. Salah satu faktor pendukung tercapainya Visi PPNS untuk menjadi Politeknik Unggul Bereputasi Global di bidang Maritim dan penunjangnya adalah reputasi dan kualitas proses pembelajaran yang baik. Hal ini mendorong PPNS untuk membangun mekanisme pengelolaan pembelajaran dalam pola pikir sistem. Untuk mendukung program pendidikan yang ada di PPNS, Kompetensi dosen sangat diperlukan dalam proses pendidikan. Oleh karena itu, diperlukan data pendukung salah satunya yaitu melalui kepuasan mahasiswa terhadap kinerja dosen, khususnya dalam proses pendidikan dan pengajaran. Pengolahan data tersebut dapat dilakukan dengan metode algorima K-Means. Berdasarkan hasil cluster Dengan K-Means didapatkan empat kelompok. Cluster pertama, adalah kelompok dosen dengan nilai Pedagogik, profesional, kepribadian, dan sosial paling rendah dengan rata-rata EPD 2,38, cluster kedua memiliki EPD dengan ratarata 3,04, cluster ketiga memiliki EPD dengan rata-rata 3,31, dan cluster keempat memiliki rata-rata EPD tertinggi mencapai 3,55.
\end{abstract}

Kata Kunci: EPD, Pembelajaran, K-Means

\section{ABSTRACTS}

As a vocational institution in the field of Maritime and Industrial Engineering Technology as well as their supporting technology, Shipbuilding Institute of Polytechnic Surabaya or Politeknik Perkapalan Negeri Surabaya (PPNS) always intends to execute Its Vision and Mission well. One of the supporting factors in achieving the Vision, that is to be a reputable Polytechnic with a global recognition, is the great reputation and quality of the learning process. This reason encourages PPNS to develop learning management mechanisms in the form of mindset system. Therefore, the competences of lecturer in the process of education are required to support the educational programs. To achieve the goal, supporting data which one of them is the students' satisfaction toward the lecturers' performance, especially in education and teaching learning process is needed. The data processing could be obtained by the K-means method. Based on the clustering result of K-Means, there were four groups which are differentiated from the average value of EPD. The first cluster is the group of lecturers with the lowest average value of EPD that is 2.38, in the field of pedagogic, professional, personality, and social. The second cluster is those lecturers who have an EPD with an average of 3.04. The third cluster is the lecturers who have an average EPD of 3.31, while the fourth cluster is the lecturers who have the highest average EPD with a value of 3.55 .

Kata Kunci: EPD, learning, K-Means

\section{PENDAHULUAN}

Politeknik Perkapalan Negeri Surabaya (PPNS) merupakan Perguruan Tinggi pendidikan vokasi yang bergerak di bidang perkapalan dan teknologi. Salah satu faktor pendukung tercapainya Visi PPNS untuk menjadi Politeknik Unggul Bereputasi Global di bidang Maritim dan penunjangnya adalah reputasi dan kualitas proses pembelajaran yang baik. Hal ini mendorong PPNS untuk membangun mekanisme pengelolaan pembelajaran dalam pola pikir sistem [1]. Sistem pembelajaran dibangun berdasarkan perencanaan yang relevan dengan tujuan, ranah belajar dan hierarkinya. Pembelajaran dilaksanakan menggunakan berbagai strategi dan teknik yang menantang, mendorong mahasiswa untuk berpikir kritis bereksplorasi, berkreasi dan bereksperimen dengan memanfaatkan aneka sumber. Politeknik memiliki dua konsep yang diimplementasikan dan mempengaruhi proses belajar mengajar di PPNS. Proses pertama Teaching Factory atau disebut juga Production Based Learning atau pembelajaran berbasis produksi. Mahasiswa akan belajar memproduksi dan melakukan pekerjaan layaknya di industri. Kedua adalah Link and Match yaitu Kurikulum dan materi perkuliahan disesuaikan dengan kebutuhan industri. PPNS telah memiliki beberapa kerjasama dalam Industrial Advisory Board dimana salah satu fungsi utamanya adalah pemutakhiran kurikulum [2,3]. Pelaksanaan pembelajaran memiliki mekanisme untuk 
memonitor, mengkaji, dan memperbaiki secara periodik kegiatan perkuliahan (kehadiran dosen dan mahasiswa), penyusunan materi perkuliahan, serta penilaian hasil belajar.

Monitoring adalah pemantauan yang dapat dijelaskan sebagai kesadaran (awareness) tentang apa yang ingin diketahui, pemantauan berkadar tingkat tinggi dilakukan agar dapat membuat pengukuran melalui waktu yang menunjukkan pergerakan ke arah tujuan atau menjauh dari itu. Monitoring akan memberikan informasi tentang status dan kecenderungan bahwa pengukuran dan evaluasi yang diselesaikan berulang dari waktu ke waktu, pemantauan umumnya dilakukan untuk tujuan tertentu. Monitoring menyediakan data dasar untuk menjawab permasalahan, sedangkan evaluasi adalah memposisikan data-data tersebut agar dapat digunakan dan diharapkan memberikan nilai tambah. Dari hasil penelitian ini diperoleh pengkayaan informasi terkait evaluasi proses pembelajaran di PPNS untuk meraih akreditasi Institusi A. Untuk mendukung program pendidikan yang ada di PPNS, Kompetensi dosen sangat diperlukan dalam proses pendidikan. Dosen harus mempunyai kualifikasi yang diperlukan bagi penyampaian ilmunya kepada mahasiswa [4].

Oleh karena itu, diperlukan data pendukung salah satunya yaitu melalui kepuasan mahasiswa terhadap kinerja dosen khususnya dalam proses pendidikan dan pengajaran. Pengolahan data tersebut dapat dilakukan dengan metode cluster analysis. Data akan diolah dengan melakukan pemetaan kinerja dosen dengan kriteria Indeks Prestasi Dosen (IPD). Ada empat aspek dalam penilaian IPD yaitu pedagogik, profesional, kepribadian, dan sosial. Nurzahputra (2017) pada penelitiannya melakukan clustering data dosen berdasarkan indeks kepuasan mahasiswa dengan menggunan algoritma K-means [5]

Penelitian ini bertujuan untuk mengukur, mengkaji, dan membangun cluster hasil proses pembelajaran di PPNS pada tahap masukan dan proses. Data dosen yang akan digunakan pada penelitian ini adalah data IPD dosen Teknik Kelistrikan Kapal PPNS. Pemetaan atau cluster dosen dalam penelitian ini akan menggunakan metode k-means clustering. Metode Algoritma KMeans merupakan model centroid. Centroid adalah titik tengah suatu cluster. Centroid digunakan untuk menghitung jarak suatu objek data terhadap centroid. Sehingga memungkinkan untuk menentukan jumlah cluster diawal penelitian. Cluster analysis dilakukan melalui pendekatan algoritm K-means. Nurzahputra (2017) menggunakan K-means cluster dalam menilai dosen berdasarkan untuk menilai Indeks Kepuasan Mahasiswa [5]. Dengan adanya hasil cluster akan mengahasilkan suatu analisis yang lebih menyeluruh untuk perbaikan sistem evaluasi kinerja dosen yang lebih efektif

\section{METODOLOGI}

\subsection{Indeks Prestasi Dosen (IPD)}

Indeks Prestasi Dosen (IPD) merupakan bagian dari monitoring dan evaluasi dosen dalam hal pengajaran. Kinerja dosen pada suatu perguruan tinggi merupakan perilaku nyata yang ditampilkan setiap dosen sebagai prestasi kerja yang dihasilkan oleh dosen tersebut. Untuk dapat menentukan kualitas kinerja dosen perlu adanya kriteria yang jelas. Purwanto (2010) menyatakan bahwa kinerja meliputi beberapa aspek, yaitu: aspek kualitas pekerjaan, ketepatan waktu, kemampuan dan komunikasi [6].

Evaluasi hasil pembelajaran atau evaluasi hasil belajar antara lain menggunakan tes untuk melakukan pengukuran hasil belajar sebagai prestasi belajar, dalam hal ini adalah penguasaan kompetensi oleh setiap mahasiswa [3]. Terkait dengan ketiga jenis evaluasi pembelajaran tersebut, dalam praktek pembelajaran secara umum pelaksanaan evaluasi pembelajaran menekankan pada evaluasi proses pembelajaran atau evaluasi manajerial, dan evaluasi hasil belajar atau evaluasi substansial. Hal ini didasarkan pada pemikiran bahwa dalam pelaksanaan pembelajaran kedua jenis evaluasi tersebut merupakan komponen sistem pembelajaran yang sangat penting. Evaluasi kedua jenis komponen yang dapat dipergunakan untuk mengetahui kekuatan dan kelemahan pelaksanaan dan hasil pembelajaran. Selanjutnya masukan tersebut pada gilirannya dipergunakan sebagai bahan dan dasar memperbaiki kualitas proses pembelajaran menuju ke perbaikan kualitas hasil pembelajaran.

\subsection{Analisis Cluster}

Analisis cluster atau biasa disebut analisis kelompok digunakan untuk mengelompokkan objek pengamatan berdasarkan karakteristik-karakteristik yang dimiliki. Pengelompokkan dilakukan dengan memaksimalkan kehomogenan objek pengamatan dalam satu cluster sekaligus memaksimalkan keheterogenan antar cluster. Analisis kelompok terdiri atas prosedur hierarki dan non-hierarki [7]

Prosedur cluster hierarki terdiri atas dua metode yaitu agglomerative dan divisive. Pada metode agglomerative langkah pertama adalah masingmasing objek pengamatan dijadikan sebagai kelompok. Langkah selanjutnya adalah dua kelompok atau objek yang memiliki jarak terdekat dikombinasikan ke dalam satu kelompok. Beberapa algoritma metode agglomerative yang digunakan untuk membentuk kelompok (cluster) adalah single linkage, complete linkage, dan average linkage. 
Algoritma tersebut dihitung berdasarkan jarak antar kelompok [8].

\subsection{K-Means Clustering}

K-Means merupakan salah satu metode data clustering nonhirarki yang berusaha mempartisi data kedalam bentuk satu atau lebih kelompok. Metode ini mempartisi data ke dalam kelompok sehingga data yang memiliki karakteristik yang sama dikelompokan ke dalam satu kelompok yang sama dan data yang mempunyai karakteristik yang berbeda dikelompokan kedalam kelompok lain. Adapun tujuan dari pengelompokan data untuk meminimalisasikan objective function yang diset dalam proses pengelompokan, yang pada umumnya berusaha meninimalisasikan variasi antar kelompok [9]

Metode K-means merupakan metode yang alogoritmanya mendeskripsikan bahwa tiap-tiap item yang dikelompokan memiliki centroid atau rata-rata yang terdekat. Adapun langkah-langkah dalam K-means adalah berikut [8].

1. Membagi item-item ke dalam $k$-kelompok.

2. Menghitung nilai centroid dengan rumus sebagai berikut.

$$
v_{i j}=\frac{\sum_{k=1}^{N_{i}} x_{k j}}{N_{i}}
$$

dimana:

$v_{i j}$ adalah centroid/rata-rata klaster ke- $i$ untuk variabel ke-j.

$N_{i}$ adalah jumlah data yang menjadi anggota klaster ke- $i$.

$i, k$ adalah indeks dari klaster.

$j$ adalah indeks dari variabel.

$x_{k j}$ adalah nilai data ke- $k$ yang ada di dalam klaster tersebut untuk variabel ke-j.

3. Kemudian mengelompokkan item berdasarkan centroid terdekat (jarak yang digunakan adalah jarak euclidean), dengan rumus sebagai berikut.

$$
D_{e}=\sqrt{\left(\sum_{i=1}^{p}\left(x_{i}-s_{i}\right)^{2}\right)}
$$

dimana:

$D_{e}$ adalah jarak Euclidean

$i$ adalah banyaknya objek.

$p$ adalah banyak variabel.

$x$ merupakan koordinat objek.

$s$ merupakan koordinat centroid.

4. Menghitung kembali centroid kelompok ketika menerima item baru maupun item yang keluar.

5. Melakukan iterasi 2 dan 3 hingga tidak ada lagi item yang bisa masuk maupun keluar lagi dimana kriteria konvergensi terpenuhi.

\subsection{Tahapan Penelitian}

Proses utama dalam penelitian ini adalah membuat cluster dosen berdasarkan dimensi IPD yaitu pedagogik, profesional, kepribadian, dan sosial. Data yang akan dilakukan dalam penelitian ini adalah data sekunder yaitu data hasil Indeks Prestasi Dosen (IPD) yang diisi oleh mahasiswa pada tahun ajaran 2017/2018. Data yang diambil adalah data sampel dari satu jurusan Teknik Kelistrikan Kapal dengan jumlah dosen sebanyak 30 orang. Data digunakan dalam penelitian ini adalah data sekunder yaitu data hasil Indeks Prestasi Dosen (IPD) yang diisi oleh mahasiswa pada tahun ajaran 2017/2018. Variabel penelitian terdiri dari empat aspek utama penyusun IPD yaitu Pedagogik (Y1), Profesional (Y2), Kepribadian (Y3), dan Sosial (Y4). Berikut ini merupakan beberapa langkahlangkah analisis yang digunakan pada penelitian ini:

1. Kajian pustaka

Kajian pustaka terus dilakukan selama penelitian berlangsung untuk meningkatkan pengetahuan pelaksana kegiatan. Kajian pustaka dilakukan dengan melakukan telaah buku-buku dan artikelartikel yang bersesuaian dengan penelitian yang sedang dilaksanakan.

\section{Pengambilan data}

Pengambilan data sekunder Indeks Prestasi Dosen (IPD) beserta Atributnya untuk jurusan Teknik Kelistrikan Kapal. untuk diolah dengan menggunakan K-Mean Clustering. Teknik pengolahan dan intepretasi data.

\begin{tabular}{|c|c|c|c|c|}
\hline $\begin{array}{l}\text { Variabel } \\
\text { Data }\end{array}$ & $\mathbf{Y}_{1}$ & $\mathbf{Y}_{2}$ & $\mathbf{Y}_{3}$ & $\mathbf{Y}_{4}$ \\
\hline 1 & $\mathrm{Y}_{11}$ & $Y_{12}$ & $\mathrm{Y}_{13}$ & $\mathrm{Y}_{14}$ \\
\hline 2 & $Y_{21}$ & $Y_{22}$ & $\mathrm{Y}_{23}$ & $\mathrm{Y}_{24}$ \\
\hline . & . & . & . & $\cdot$ \\
\hline $\mathrm{n}$ & $\mathrm{Y}_{\mathrm{n} 1}$ & $Y_{n 2}$ & $\mathrm{Y}_{\mathrm{n} 3}$ & $\mathrm{Y}_{\mathrm{n} 4}$ \\
\hline
\end{tabular}

Tabel 1 Stuktur Data Clustering

Berikut ini merupakan beberapa langkah analisis yang digunakan pada penelitian ini:

1. Melakukan kajian tentang K-Means Clustering

2. Menyusun matriks ukuran $N \mathrm{x} p$, dimana $N$ merupakan banyaknya observasi (Dosen PPNS) dan $p$ adalah banyaknya variabel (Dimensi penyusun IPD).

3. Melakukan analisis statistika deskriptif pada semua variabel.

4. Melakukan uji normal multivariat pada semua variabel.

5. Melakukan uji Kaiser Meyer Olkin dan uji Bartlett pada semua variabel untuk 
mengetahui kecupukan data dan ada tidaknya korelasi antar variabel.

6. Melakukan standardisasi/transformasi pada semua variabel.

7. Melakukan pengelompokan dengan metode $K$-Means Clustering dengan tahapan sebagai berikut:

i. Melakukan percobaan dengan membagi item-item ke dalam 2 hingga 5 kelompok.

ii. Melakukan perbandingan antar kelompok hingga menemukan kelompok yang optimum.

iii. Melakukan pengelompokan terhadap Dosen berdasarkan hasil dari kelompok yang optimum.

iv. Mendapatkan kelompok berdasarkan dari hasil pengelompokan terbaik.

8. Menggambarkan peta cluster dosen berdasarkan hasil K-Means

9. Melakukan Interpretasi data dari hasil pengelompokan, dan menjelaskan kriteria masing-masing kelompok dosen berdasarkan IPD. Sehingga bisa dipetakan Kompetensi mengajar dosen PPNS.

10. Menyusun Rekomendasi.

\section{Penarikan kesimpulan}

Seluruh rangkaian kegiatan di atas akan dilaporkan dalam bentuk sebuah laporan akhir. Laporan akhir berisi penjelasan pelaksanaan kegiatan penelitian dan pembahasan hasil dan analisa penelitian yang telah dilakukan.

\section{PEMBAHASAN}

Kriteria yang digunakan berdasarkan empat kompetensi. Pertama kompetensi Pedagogik yang merupakan kemampuan pemahaman terhadap peserta didik, perancangan dan pelaksanaan pembelajaran, evaluasi hasil belajar, dan pengembangan peserta didik untuk mengaktualisasikan berbagai potensi yang dimilikinya. Kedua, Kompetensi Kepribadian adalah kemampuan personal yang mencerminkan kepribadian yang mantap, stabil, dewasa, arif dan berwibawa, menjadi teladan bagi peserta didik, dan berakhlak mulia. Ketiga, Kompetensi Profesional adalah penguasaan materi pembelajaran secara luas dan mendalam, yang mencakup penguasaan materi kurikulum mata pelajaran di sekolah dan substansi keilmuan yang menaungi materinya, serta penguasaan terhadap struktur dan metodologi keilmuannya. Keempat, Kompetensi Sosial adalah kemampuan dosen untuk berkomunikasi dan bergaul secara efektif dengan peserta didik, tenaga kependidikan, orang tua/wali peserta didik, dan masyarakat sekitar.
Berikut ini hasil Cluster Dosen Jurusan Teknik Kelistrikan Kapal PPNS berdasarkan keriteria IPD Dengan menggunakan metode $K$ Means Clustering. Iterasi proses $K$-Means berhenti saat iterasi KETIGA. Cluster dibentuk menjadi empat kelompok dengan final cluster center sesuai tabel 2 .

Tabel 2 Final Cluster Center

\begin{tabular}{|l|c|c|c|c|}
\hline \multirow{2}{*}{} & \multicolumn{4}{|c|}{ Cluster } \\
\cline { 2 - 5 } & 1 & 2 & 3 & 4 \\
\hline Pedagogik & 1.41 & 3.34 & 3.09 & 3.63 \\
Profesional & 1.39 & 3.34 & 3.05 & 3.64 \\
Kepribadian & 1.32 & 3.31 & 2.93 & 3.64 \\
Sosial & 1.40 & 3.31 & 3.09 & 3.64 \\
\hline
\end{tabular}

- Cluster 1

Berdasarkan pengelompokan dengan menggunakan K-Means Clustering, Kelompok 1 terdiri dari satu orang dosen. Kelompok 1 adalah dosen dengan nilai Pedagogik, Profesional, Kepribadian, dan Sosial yang relatif rendah jika dibandingkan dengan kelompok lain. Yaitu nilai rata-rata pedagogik 2,41, profesional 2,39, kperibadian 2,32, dan sosial 2,4

\section{- Cluster 2}

Berdasarkan pengelompokan dengan menggunakan K-Means Clustering, Kelompok 2 terdiri dari satu orang dosen. Kelompok 2 adalah dosen dengan nilai Pedagogik, Profesional, Kepribadian, dan Sosial lebih tinggi dibandingkan dengan kelompok 1. Kelompok 2 adalah dosen dengan nilai Pedagogik, Profesional, Kepribadian, dan Sosial yang relatif rendah jika dibandingkan dengan kelompok lain. Yaitu nilai rata-rata pedagogik 3,09, profesional 3,05, kperibadian 2,93, dan sosial 3,09.

\section{- $\quad$ Cluster 3}

Berdasarkan pengelompokan dengan menggunakan K-Means Clustering, Kelompok 3 terdiri dari tiga belas dosen. Kelompok 3 adalah dosen dengan nilai Pedagogik, Profesional, Kepribadian, dan Sosial lebih tinggi dibandingkan dengan kelompok 1 dan 2. Kelompok 3 memiliki rata-rata nilai Pedagogik 3,31, dengan nilai Standar deviasi 0,08, Sedangkan nilai minimum sebesar 3,17, dan Paling tinggi sebesar 3,48. Nilai Profesional pada Kelompok 3 rata-rata 3,3, dengan nilai standar deviasi 0,06 , sedangkan nilai minimum sebesar 3,19 dan Maksimum sebesar 3,38. 
Tabel 3. Karakteristik kelompok 3

\begin{tabular}{|c|c|c|c|c|}
\hline & Pedagogik & Profesional & $\begin{array}{l}\text { Kepriba- } \\
\text { dian }\end{array}$ & Sosial \\
\hline Mean & 3.31 & 3.30 & 3.31 & 3.32 \\
\hline STD & 0.08 & 0.06 & 0.09 & 0.06 \\
\hline Min & 3.17 & 3.19 & 3.17 & 3.20 \\
\hline Maks & 3.48 & 3.38 & 3.54 & 3.39 \\
\hline
\end{tabular}

Nilai Kepribadian pada Kelompok 3 rata-rata 3,31, dengan nilai standar deviasi 0,09, sedangkan nilai minimum sebesar 3,17 dan Maksimum sebesar 3,54 . Kriteria terakhir adalah Sosial dengan rata-rata 3,32, standar deviasi 0,06, nilai minimum 3,20, dan maksimum 3,39.

\section{- Cluster 4}

Berdasarkan pengelompokan dengan menggunakan K-Means Clustering, Kelompok 4 terdiri dari lima belas dosen. Kelompok 4 adalah dosen dengan nilai Pedagogik, Profesional, Kepribadian, dan Sosial paling tinggi dibandingkan kelompok yang lain. Kelompok 4 memiliki rata-rata nilai Pedagogik 3,55, dengan nilai Standar deviasi 0,05 , Sedangkan nilai minimum sebesar 3,47, dan Paling tinggi sebesar 3,63. Nilai Profesional pada Kelompok 4 rata-rata 3,54 , dengan nilai standar deviasi 0,05 , sedangkan nilai minimum sebesar 3,46 dan Maksimum sebesar 3,64.

Tabel 4. Karakteristik kelompok 4

\begin{tabular}{|c|c|r|r|r|}
\hline & Pedagogik & Profesional & $\begin{array}{c}\text { Kepriba- } \\
\text { dian }\end{array}$ & \multicolumn{1}{c|}{ Sosial } \\
\hline Mean & 3.81 & 3.81 & 3.81 & 3.79 \\
\hline STD & 0.12 & 0.09 & 0.10 & 0.12 \\
\hline Min & 3.73 & 3.74 & 3.74 & 3.70 \\
\hline Maks & 3.89 & 3.88 & 3.88 & 3.88 \\
\hline
\end{tabular}

Nilai Kepribadian pada Kelompok 4 rata-rata 3,55 , dengan nilai standar deviasi 0,07, sedangkan nilai minimum sebesar 3,42 dan Maksimum sebesar 3,67 . Kriteria terakhir adalah Sosial dengan rata-rata 3,54, standar deviasi 0,06, nilai minimum 3,44, dan maksimum 3,64.

Tabel 5. Analisis varians

\begin{tabular}{|c|c|c|c|c|}
\hline & $\begin{array}{c}\text { Mean } \\
\text { Square }\end{array}$ & df & F & Sig. \\
\hline Pedagogik & .005 & 26 & 317.723 & .000 \\
\hline Profesional & .003 & 26 & 450.125 & .000 \\
\hline Kepribadian & .007 & 26 & 236.527 & .000 \\
\hline Sosial & .005 & 26 & 317.723 & .000 \\
\hline
\end{tabular}

Berdasarkan Hasil Tabel ANOVA untuk melihat perbedaan masing-masing kelompok berdasarkan kriteria pedagogik, profesionl, kepribadian dan sosial dapat disimpulkan antar kelompok memiliki perbedaan yang signifikan. Kesimpulan ini didaptkan dari nilai P-Value $(0,00)$ yang lebih kecil dari $\alpha(0,05)$.

\section{KESIMPULAN}

Berdasarkan analisis cluster dosen Teknik Kelistrikan Kapal denga metode K-Means didapatkan empat kelompok dosen berdasarkan kriteria IPD. Iterasi dilakukan sampai iterasi ketiga dengan karakteristik kelompok sebagai berikut:

a. Kelompok 1 terdiri dari satu dosen. Kelompok 1 adalah dosen dengan nilai Pedagogik, Profesional, Kepribadian, dan Sosial yang relatif rendah jika dibandingkan dengan kelompok lain.

b. Kelompok 2 juga terdiri dari satu dosen dengan nilai Pedagogik, Profesional, Kepribadian, dan Sosial lebih tinggi dibandingkan dengan kelompok 1.

c. Kelompok 3 terdiri dari tiga belas dosen dengan nilai Pedagogik, Profesional, Kepribadian, dan Sosial lebih tinggi dibandingkan dengan kelompok 1 dan 2.

d. Kelompok 4 terdiri dari lima belas dosen dengan nilai Pedagogik, Profesional, Kepribadian, dan Sosial paling tinggi dibandingkan kelompok yang lain.

\section{PUSTAKA}

Tim Borang Pengelola PPNS. (2017). Borang Pengelola Akreditasi. Surabaya: PPNS.

Tim Renstra. (2015). Rencana Strategis PPNS 2015-2019. Surabaya: PPNS.

Tim Monev Pembelajaran PPNS. (2017). Pedoman Monev Pembelajaraan PPNS 2017. Surabaya: PPNS

Sugiharti, E., \& Muslim, M. A., (2016), On-line Clustering of Lecturers Performance of Computer Science Department of Semarang State University Using K-Means Algorithm, Journal of Theoretical and Applied Information Technology, 83(1).

Nurzahputra, A., Muslim, M. A., Khusniati, M., (2017), Application of K-Means Algorithm for Clustering Lecturer Based On Assessment of Student Satisfaction Index, Journal of Theoretical and Applied Information Technology, Vol.16., No.1.

Purwanto.M.H. (2010). Administrasi dan Supervisi Pendidikan. Remaja Rosdakarya. Bandung.

Hair, J. F., Black, W. C., Babin, B. J., Anderson, R. E. (2010). "Multivariate Data Analysis". Seventh Edition.

Johnson, R.A. dan Wichern, D.W. (2007). Applied Multivariate Statistical Analysis,6thed. Prentice Hall International Inc. 
Agusta, Y. (2007). "K-Means Penerapan, Permasalahan dan Metode Terkait. Jurnal Sistem dan Informatika". Vol.3: 47-60. 